\title{
HUKUMAN RAJAM BAGI PELAKU ZINA MUHSHAN \\ DALAM HUKUM PIDANA ISLAM
}

\author{
Oleh: Rokhmadi
}

\begin{abstract}
Fakultas Syari'ah dan Hukum Universitas Islam Negeri Walisongo Email:rokhmadi66@yahoo.com
\end{abstract}

\begin{abstract}
Abstrak
Hukuman rajam adalah hukuman mati dengan cara dilempari batu atau sejenisnya sampai mati. Keberadaan hukuman rajam dalam ketentuan hukum pidana Islam ini merupakan hukuman yang telah diterima oleh hampir semua fuqaha, kecuali kelompok Azariqah dari golongan Khawarij. Menurut mereka hukuman untuk jarimah zina, baik mubshan maupun ghairu mubshan adalah hukuman jilid seratus kali berdasarkan firman Allah dalam QS. al-Nur: 2, sehingga mereka tidak menerapkan hukuman rajam bagi pelaku zina muhshan. Sedangkan fuqaha' yang menyepakati hukuman rajam bagi pelaku zina muhshan berpendapat bahwa hadits shahih yang berkenaan dengan hukuman rajam dapat mentakhsis QS. al-Nur: 2 tersebut di atas.

Hasil penelitian ini adalah jika dilihat dari setting historis, maka penetapan hukuman rajam bagi pelaku zina mubshan itu didasarkan kepada hadits Nabi, baik secara qauliyah maupun fi'liyah. Akan tetapi, ada kesulitan dalam membedakan antara status teks sunnah mengenai apakah teks sunnah tersebut menjelaskan wahyu atau tidak. Hal ini dapat disimpulkan bahwa hukuman rajam dalam hukum pidana Islam itu bukan berasal dari syari'at Islam itu sendiri semata-mata, tetapi yang pasti bahwa hukuman rajam adalah berdasarkan nash atau ajaran agama sebelumnya, yaitu nash dalam Kitab Taurat. Hal ini dapat dilacak dari dasar normatif yaitu hadits-hadits Nabi yang mengacu kepada penerapan hukuman rajam bagi pelaku zina mubshan. Setidaknya Rasulullah saw., telah empat kali melaksanakan atau minimal memberitahukan pelaksanaan hukuman rajam bagi pelaku zina mubshan.
\end{abstract}

Kata Kunci: Zina muhshan; rajam; nash; hukum pidana.

\section{A. Pendahuluan}

Hukum pidana Islam dan hukum pidana positif berbeda pandangan dalam masalah hadd (hukuman) zina. Hukum pidana Islam memandang bahwa setiap pelaku zina atau orang yang melakukan hubungan kelamin di luar nikah diancam dengan hukuman, baik 
pelakunya sudah kawin atau belum, baik dilakukan suka sama suka atau tidak, karena jarimah (tindak pidana) zina dalam hukum Islam masuk kedalam kategorisasi jarimah budud. Jarimah hudud yaitu jarimah (tindak pidana) yang telah ditentukan macam dan jumlahnya yang menjadi hak Allah, yaitu hak masyarakat artinya hakim (penguasa) hanya berkewajiban untuk menjatuhkan hukuman berdasarkan al-Qur'an dan al-Sunnah dan tidak berhak menambah atau mengurangi hukumannya. ${ }^{1}$ Sebaliknya, hukum pidana positif tidak memandang semua hubungan kelamin di luar perkawinan sebagai zina. Pada dasarnya yang dianggap zina menurut hukum pidana positif itu hanyalah hubungan kelamin diluar perkawinan, yang dilakukan oleh orang-orang yang berada dalam status bersuami atau beristri saja. ${ }^{2}$

Mengenai hukuman bagi pezina, nampaknya para Ulama' bersepakat untuk mengkategorikan sesuai dengan status yang disandang oleh pelaku tersebut. Penetapan hukuman zina ini didasarkan atas sebuah hadits yang diriwayatkan dari 'Ubadah bin al-Shamit Rasulullah Saw., pernah bersabda:

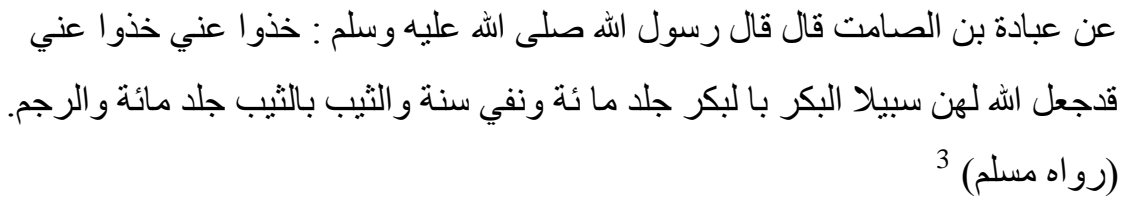

Artinya: Dari Ubadah bin al-Shamit ia berkata: Rasulullah Saw., bersabda: "Ambillah dari diriku, ambillah dari diriku, sesunggubnya Allah telah memberi jalan keluar (bukuman) untuk mereka (pezina). Jejaka dan perawan yang berzina bukumannya didera seratus kali dan pengasingan selama satu tabun, sedangkan duda dan janda yang berzina bukumannya didera seratus kali dan dirajam". (HR. Muslim)

Pernyataan hadits di atas juga bersumber pada ayat al-Qur'an yang tidak tertulis (ghairu ma'tsurat) dalam Kitab al-Qur'an Mushaf Usmany yaitu;

\footnotetext{
1 'Abd al-Qadir 'Audah, Al-Tasyri' al-Jinaiy al-Islamiy Muqaranan bi al-Qanun al-Wadl'iy, Juz II, Beirut: Dar al-Kitab al-Arabi, t.th., hlm. 102.

2 Untuk mengetahui selengkapnya mengenai aturan hukum tersebut lihat pasal 284 KUHP.

${ }^{3}$ Imam Abi Husain Muslim bin Hajjaj al-Qusairy al-Nasaburiy, Shabih Muslim, juz II, Baeirut: Dar al-Kitab al-Ilmiyah, t.th., hlm. 48.
} 
وفى رواية ابى معشر الاتى بلفظ قد قرأنا: الثيخ و الثيخة إذا زنيا فارجمو هما البتة نكالا

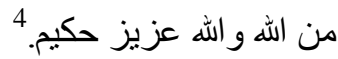

Artinya: Di dalam riwayat Abi Mu'syar, kita benar-benar telah membaca ayat itu dengan lafadz; "Tika orang laki-laki dan orang perempuan (dewasa/ telah kawin) melakukan perzinaan, maka rajamlab keduanya, karena mereka durhaka kepada Allah, Sesunggubnya Allah Maha Perkasa dan Maha Bijaksana".

Dari hadits dan ayat tersebut di atas dapat diketahui bahwa hukuman zina itu ada dua macam, tergantung kepada keadaan pelakunya apakah ia belum berkeluarga (ghairu mubshan) atau sudah berkeluarga (mubshan). ${ }^{5}$

Untuk memperjelas masalah tersebut, maka akan diuraikan sebagai berikut;

\section{a. Zina Ghairu Muhshan}

Zina ghairu mubshan adalah zina yang dilakukan oleh seorang laki-laki dan perempuan yang belum berkeluarga (belum kawin). Hukuman zina untuk ghairu muhshan ini ada dua macam: didera seratus kali dan diasingkan/dipenjara selama satu tahun.

\section{b. Zina Muhshan}

Zina mubshan adalah zina yang dilakukan oleh seorang laki-laki dan perempuan yang sudah/pernah terikat oleh perkawinan (bersuami atau beristri). Hukuman untuk pelaku zina mubshan ini ada dua macam; didera seratus kali dan dirajam. ${ }^{6}$

Hukuman rajam adalah hukuman mati dengan cara dilempari batu atau sejenisnya sampai mati. ${ }^{7}$ Hukuman rajam merupakan hukuman yang telah diterima oleh hampir semua fuqaha, kecuali kelompok Azariqah dari golongan Khawarij. Menurut mereka hukuman untuk jarimah zina, baik mubshan maupun ghairu mubshan adalah hukuman dera seratus kali berdasarkan firman Allah dalam surat al-Nur ayat 2;

\footnotetext{
${ }^{4}$ Ahmad Ali bin Hajar, Fath al-Bariy, Juz 12, Beirut: Dar al-Fikr, t.th., hlm. 143.

5 Ahmad Wardi Muslich, Pengantar dan Asas Hukum Pidana Islam, cet. II, Jakarta: Sinar Grafika, 2006. Hlm. 29.

${ }^{6}$ Ibid., hlm. 33.

7 'Abd al-Qadir 'Audah, op.cit., hlm. 384.
} 


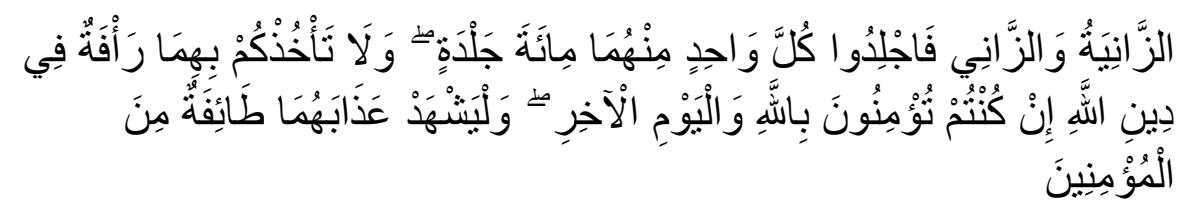

Artinya: Perempuan yang berizina dan laki-laki yang berzina, maka deralah tiaptiap seorang dari keduanya seratus dali dera, dan janganlah belas kasiban kepada keduanya mencegah kamu untuk (menjalankan) agama Allah, jika kamu beriman kepada Allah, dan hari akbirat, dan hendaklah (pelaksanaan) bukuman mereka disaksikan oleh sekumpulan orangorang yang beriman.

Sebuah permasalahan yang sangat pelik ketika rajam sangat dipertanyakan ketetapan hukumnya oleh banyak orang, sebagaimana halnya sebuah ketakutan yang dialami oleh Khalifah kedua yaitu 'Umar bin al-Khaththab yang tertuang dalam hadits berikut ini;

$$
\begin{aligned}
& \text { عن عمر بن الخطاب انه قال: إن الله قد بعث محمدا صلى الله عليه وسلم بالحق و انزل عليه }
\end{aligned}
$$

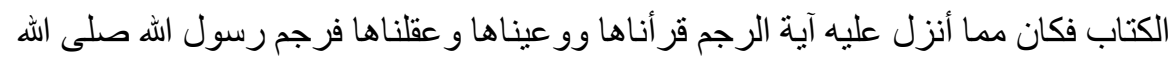

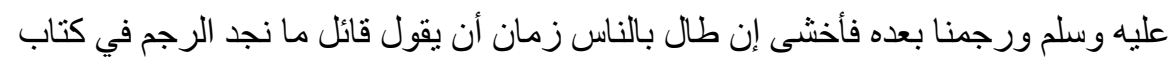

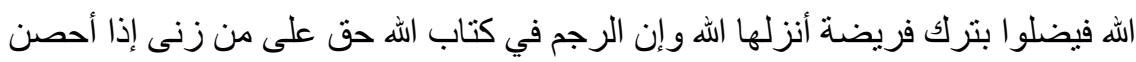

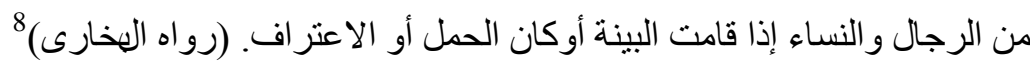

Artinya: Dari Umar bin Khaththab bahwasannya dia berkata : Sesunggubnya Allah telah mengutus Muhammad dengan sebenar-benarnya dan telah pula menurunkan kepadanya sebuah kitab suci itu terdapat "Ayat Rajam" yang telah kita baca, fahami serta menyadarinya bersama. Rasulullah sendiri pernah melaksanakan rajam dan setelah itu kita pun melakukannya. Hal ini saya tegaskan kembali lantaran aku khawatir, karena telah berselang waktu akan ada seseorang yang mengatakan: "Demi Allab kami tidak mendapatkan ayat rajam dalam kitabullab". Dengan meninggalkan suatu kewajiban yang benar-benar diturunkan Allah, maka mereka telah menjadi sesat. Hukuman rajam yang terdapat dalam kitabullah itu harus dijatubkan kepada laki-laki maupun perempuan yang berbuat zina mubshan, dengan syarat adanya

\footnotetext{
${ }^{8}$ Imam Abi 'Abdillah Muhammad bin Isma'il bin Ibrahim bin al-Mughirah bin Bardzbah al-Bukhari al-Ja'fiy, Shabih al-Bukhari, Beirut: Dar al-Kitab al-'Tlmiyyah, juz VII, t.th., hlm. 341.
} 
bukti-bukti, kehamilan atau pengakuan dari dirinya sendiri. (HR. Bukhari).

Berdasarkan kekhawatiran terhadap akan hilang hukuman rajam sebagaimana yang diutarakan oleh Khalifah Umar inilah, penulis berusaha menelusuri informasi tentang kejelasan sejarah sosial penerapan hukuman yang berkenaan dengan rajam bagi pelaku qina mubshan.

\section{B. Pembahasan}

\section{Sejarah Hadd Rajam bagi Pelaku Zina Muhshan dalam Hukum Pidana Islam}

Jika dilihat dari setting historis bahwa penjatuhan hukuman rajam bagi pelaku zina mubshan itu didasarkan kepada hadits Nabi, baik secara qauliyah maupun fi'liyah. Hal ini dapat dipastikan bahwa hukuman rajam dalam hukum pidana Islam itu bukan berasal dari syariat Islam sendiri yang dibawa oleh Nabi Muhammad saw, akan tetapi berdasarkan nash atau ajaran agama sebelumnya, yaitu nash yang terdapat dalam Kitab Taurat. Hal ini dapat lacak dari dasar normatif dari hukuman rajam ini adalah hadits-hadits Nabi yang mengacu pada penerapan hadd rajam bagi pelaku zina mubshan, seperti hukuman rajam yang dijatuhkan kepada Ma'iz bin Malik dan wanita Ghamidiyah yang datang menghadap langsung kepada Nabi yang mengakui perbuatan zinanya dan meminta dengan kesadaran dan kemauannya sendiri untuk dilaksanakan hukuman rajam atas dirinya, walaupun berkali-kali pula Nabi menolak pelaksanaan penerapan hukuman rajam atas diri mereka tersebut. Akan tetapi pada akhirnya setelah Rasulullah yakin atas pengakuannya, maka Rasulullah baru menjatuhkan hukuman rajam bagi mereka (kaum Yahudi) sesuai dengan isi Kitab Taurat yang telah diyakininya. Hal ini berdasarkan hadits yang diriwayatkan Muslim;

$$
\begin{aligned}
& \text { عن ابن عمرأن رسول الهه صلى الله عليه وسلم أوتي بيهودي ويهودية قد زنيا فنطلق } \\
& \text { رسول الله صلى الله عليه وسلم حتى جاء يهود فقال ما تجدون فى التوراة على من زنى } \\
& \text { قالو ا نسود وجو ههما ونحملهما ونخالف بين وجو ههما ويطاف بهما قال فأتو ا بالتور اة إن } \\
& \text { كنتم صادقين فجاءو ا بها فقر أو ها حتى إذأمروا بآية الرجم وضع الفتى الذى يقر أ يده على } \\
& \text { آية الرجم وقر أ مابين يديها ور أهاققال له عبداله بن سلام وهو مع رسول الله صلى الله }
\end{aligned}
$$




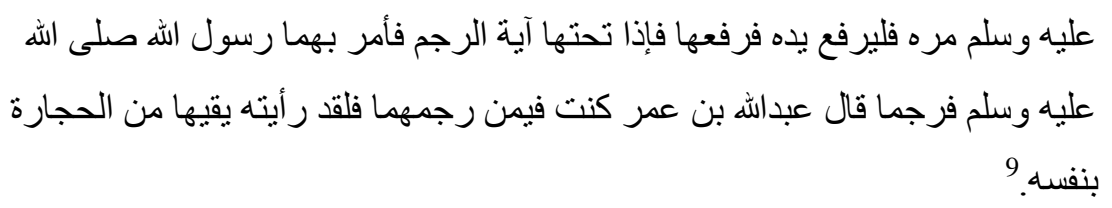

Artinya: Dari Ibnu Umar, babwasannya Rasulullah didatangi seorang lakilaki dan perempuan bangsa Yabudi yang telah melakukan perzinaan. Beliau lalu pergi kepada perkampungan Yabudi yang bersangkutan. Berkata Rasulullah saw: "Apa bukuman atas orang yang berzina di dalam kitab Taurat"?, jawab orang-orang Yahudi itu, muka pria dan wanitanya dibitamkan, dinaikekan keduanya di atas tandu dan kendaraan duduk bertemu punggung lalu diarak berkeliling. Rasulullah saw berkata: "Tika perkataan tuan-tuan itu benar, coba datangkan kitab Taurat". Lalu kitab Tauratpun didatangkan lalu dibaca oleh mereka. Setelah sampai kepada ayat rajam, maka pemuda yang membaca itu menutupinya dengan tangannya, dan dibacanya ayat yang sesudahnya. Berkata Abdullah bin Salam yang menemani Rasulullah saw: surublab ia mengangkat tangannya! Maka pemuda itu mengangkat tangannya; kiranya benarlab ayat rajam yang ditutupinya. Rasulullah saw lalu memerintahkan merajam; maka dirajamlah Kedua-duanya pria dan wanita itu. Kata 'Abdullah bin 'Umar: adalah saya sendiri ikut merajam keduanya; pada waktu itu saya libat laki-laki itu melindungi perempuan itu dengan badannya dari batu-batu yang dilemparkan kepadanya.

Berdasarkan hadits di atas, menjadi sangat jelas bahwa Nabi melaksanakan hukuman rajam bagi orang Yahudi berdasarkan kitab Taurat dan menurut al-Zarqani peristiwa ini terjadi pada bulan Zulhijjah tahun ke-4 Hijriyah. ${ }^{10}$

Sikap pengambilan keputusan itu diambil oleh Rasulullah Saw sebagai Kepala Negara (Khalifah) Negara Madinah pada saat itu. Dapat diambil kesimpulan bahwa penjatuhan hukuman atau keputusan hukum berada pada otoritas tertinggi (ulul amri) dalam syari'at untuk memberlakukan hadd tertentu terhadap orang muslim maupun non muslim. Misalnya pemahaman bahwa pelemparan batu sampai mati bagi pelaku zina yang terikat dengan perkawinan

\footnotetext{
${ }^{9}$ Imam Abi Husaen Muslim bin Hajjaj al-Qusaery al-Nasaburi, Shabih Muslim, juz II, Beirut: Dar al-Kutub al-Ilmiyah, t.th, hlm. 54.

${ }^{10}$ Muhammad bin 'Abd al-Baqi bin Yusuf al-Zarqani al-Misri al-Azhari al-Maliki, Syarh alZarqani 'ala Muwaththa', cet I, IV, Beirut: Dar al-Kutub Ilmiyah, 1990, hlm. 165.
} 
merupakan bagian hukum dari hukum Yahudi. Nabi dikabarkan telah menerapkan hukuman rajam terhadap kaum Yahudi berdasarkan pada hukum yang dipercayainya di Negara Madinah. ${ }^{11}$

Dengan demikian, berdasarkan sunnah yang telah dilaksanakan oleh Rasulullah Saw., itulah pelaksanaan hukuman rajam yang diikuti dan dilaksanakan oleh para khulafa al-rasyidin, seperti penerapan hukuman rajam yang dilakukan oleh 'Umar bin Khaththab dan 'Ali bin Abi Thalib, sebagaimana hadits yang diriwayatkan oleh al-Bukhari;

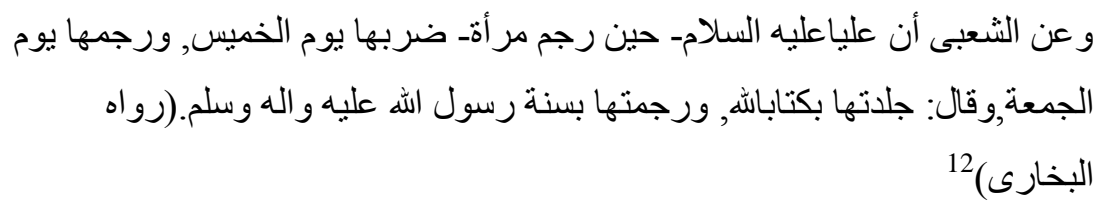

Artinya: Dari al-Sya'biy, bahwasannya 'Ali As, ketika melaksanakan bukuman rajam terbadap seorang perempuan, ia mencambuknya pada hari Kamis dan merajamnya pada hari Jumu'at. Ia berkata: aku mencambuknya berdasarkan kitab Allah, dan merajamnya berdasarkan sunnah Rasulullah 'alaibi wa alibi wa sallam”. (HR. Bukhari).

Dalam ketetapan hukum yang didasarkan pada hadits di atas dapat dipahami bahwa 'Ali memberlakukan hukuman rajam ini berdasarkan ketetapan yang diambil dari Rasulullah, bukanlah dari hukum yang terdapat dalam al-Qur'an.

Dalam kasus ini ditemukan bahwa 'Ali menjalankan hukuman bagi pelaku zina yang bernama Syurahah al-Hamdaniyah yang dilaksanakan hukuman cambuk pada hari Kamis dan merajamnya pada hari Jumu'at. ${ }^{13}$

Dengan kata lain, bahwa Khalifah 'Ali bin Abi Thalib melakukan penggabungan hukuman antara hukuman cambuk dengan hukuman rajam pada pelaku zina mubshan (yang sudah terikat dalam

\footnotetext{
11 Abdullah Ahmed an-Na'im, Dekonstruksi Syariah: Wacana Kebebasan Sipil, Hak Asasi Manusia dan Hubungan Internasional Dalam Islam, Yogyakarta: LKiS dan Pustaka Pelajar, 1994, hlm. 216.

12 Imam Abi 'Abdillah Muhammad bin Isma'il Ibnu Ibrahim bin al-Mughirah bin Bardabah al-Bukhari al-Ja'fiyy, Shabih al-Bukhariy, Beirut: Dar al-Kitab al-'Ilmiyyah, Juz VII, t.th., hlm. 335.

${ }^{13}$ Abdur Rahman, Terjemaban Bidayah al-Mujtabid, Semarang: Asy Syifa, 1990, hlm. 619.
} 
ikatan pernikahan). Patut dicatat bahwa sebagian besar hukuman rajam yang dilaksanakan oleh Nabi dan para khulafa al-rasyidin didasarkan pada pengakuannya sendiri, bukan atas dasar pembuktian oleh empat orang saksi yang telah melihat perzinaan tersebut. ${ }^{14}$

Dalam penerapan hukuman rajam yang dilakukan oleh Nabi, seperti yang telah diuraikan dalam Bab III sebelumnya banyak ditemui bahwa ketetapan yang diputuskan oleh Nabi adalah sikap kehatihatian dan tidak memutuskan secara langsung, akan tetapi meliputi proses yang sangat ketat dan juga merujuk kepada dasar hukum yang diyakini oleh mereka yang tercantum dalam Kitab Taurat, terutama perzinaan yang telah dilakukan oleh Suku Ghamidiyah sebagai salah satu pemeluk agama Yahudi.

Dengan demikian Nabi hanya semata-mata melaksanakan sesuai dengan hukuman yang telah diyakini oleh mereka, bukan semata-mata dari syari'at yang dibawa oleh Nabi yang terdapat dalam nash alQur'an.

Ketetapan hukum Islam tentang hukuman zina yang ditetapkan dengan persiapan yang tidak sembarangan, setelah memahami pembentukan dan daya pikir manusia dengan benar, menganalisis karakter, kecenderungan dan perasaannya secara teliti, dan juga setelah menetapkan untuk menjaga kemaslahatan individu dan masyarakat umum. Hukuman-hukuman ini bersifat ilmiah dan berkenaan dengan hukum. Disebut ilmiah karena ditetapkan berdasarkan psikologi manusia, dan disebut berkenaan dengan hukum, karena ditetapkan untuk memberantas tindak pidana. Inilah keistimewaan hukum Islam yang ditetapkan pada tindak pidana pada jarimah budud, dan keistimewaan ini hampir tidak ditemukan dalam hukum konvensional. ${ }^{15}$

Dengan demikian, menurut sejarah setidaknya Rasulullah telah 4 kali menjatuhkan/melaksanakan hukuman rajam bagi pelaku zina mubshan, yaitu;

1. Rajam terhadap orang Yahudi yang melaporkan dirinya kepada Nabi dan Nabi menjatuhkan hukuman berdasarkan Kitab Taurat

\footnotetext{
14 Abdur Rahman I Doi, Tindak Pidana Dalam Syari'at Islam, Jakarta: Rineka Cipta, 1992, hlm. 39.

15 Tsalisah, Ensiklopedi Hukum Islam, Jilid III, Bogor: Batara Offset, t.th, hlm. 50.
} 
yang diyakininya, dan menurut al-Zarqani peristiwa ini terjadi pada bulan Zulhijjah tahun ke-4 Hijriyah.

2. Rajam terhadap seorang perempuan yang dituduh telah berzina dengan anak laki-laki si penuduh, Setelah dikonfirmasikan ternyata perempuan tersebut mengaku sendiri, meskipun sebelumnya ada persaksian dari ayah anak yang dituduh berzina dengannya.

3. Rajam terhadap Ma’iz bin Malik, Nabi melaksanakan hukuman rajam kepadanya berdasarkan atas pengakuannya.

4. Rajam terhadap perempuan dari Suku Ghamidiyah yang sedang hamil dari perzinaan, tetapi pelaksanaan hukumannya setelah perempuan tersebut melahirkan dan menyapih anaknya, berdasarkan pengakuannya karena ia takut akan adzab Allah di akherat.

\section{Alasan dan Dasar Hukum Penerapan hukuman Rajam Bagi Pelaku Zina Muhshan}

Dalam kenyataan sejarah yang ditemukan dan dapat dilihat beberapa hadits yang disandarkan kepada sahabat menunjukkan bahwa hukuman rajam masih ditemui dan dilaksanakan pada masa khulafa al-rasyidin, seperti yang terlihat pada semangat 'Umar bin Khaththab dalam menanggapi dan memperjuangkan eksistensi hukum rajam. Keberadaan hukuman ini juga bisa ditemukan pada pelaksanaan hukuman rajam yang dilakukan oleh 'Ali bin Abi Thalib r.a.

Namun jika ditilik dari sejarah dalam pembukuan al-Qur'an, ada beberapa hal yang perlu dianalisis, bahwa dalam penetapan hukum rajam ini di klaim ada di dalam kitab Allah (al-Qur'an). Hadits dibawah ini yang dianggap bersumber pada ayat al-Qur'an yang tidak tertulis dalam Mushaf Utsmaniy.

Redaksi ayat tersebut seperti yang dilaporkan adalah demikian:

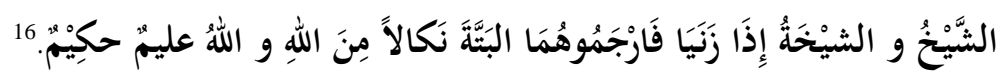

Artinya: Orang laki-laki yang telah dewasa dan orang perempuan yang telah dewasa jika keduanya berzina, maka keduanya mutlak barus

\footnotetext{
${ }^{16}$ Husain Muhammad al-Maghribiy, Al-Badru al-Tamam, Juz IV, t.tp: Dar al-Wafa, 2005, hlm. 387.
} 
dirajam, sebagai balasan dari Allah, dan Allah Maha Mengetahui dan Maha Bijaksana.

Dalam masalah hukuman rajam yang sangat pelik ini khalifah 'Umar bin Khaththab sangat menanggapi serius atas permasalahan hukuman rajam. Hal ini bisa dilihat pada isi khutbah yang isinya sebagai berikut:

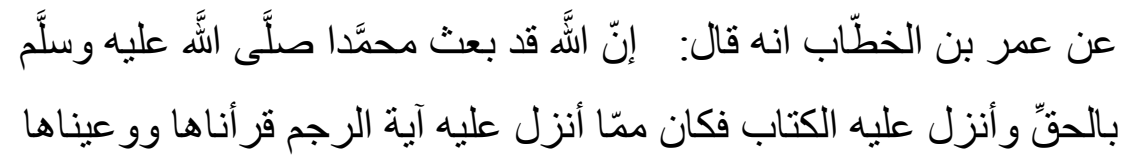

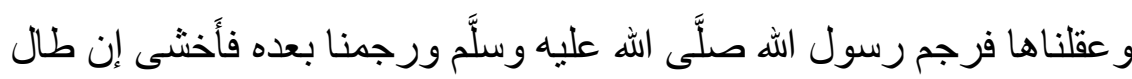

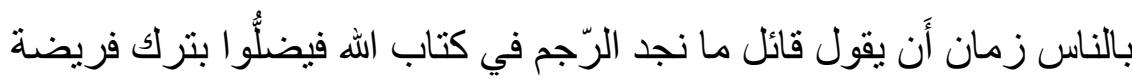
أنزلَها الله و إن الرّّم في كتاب الله حق علَى من زنى إذا أحصن من الرِّجال و النّّاء إذا قامت البينة أَو كَان الحبل أو الاعتر اف (رواه البخا رىى)

Artinya: Dari Umar bin Khaththab sesungguhnya dia berkata: Sesunggubnya Allah telah mengutus Mubammad dengan sebenar-benarnya dan telah pula menurunkan kepadanya sebuah kitab suci itu terdapat "Ayat Rajam" yang telah kita baca, kita fahami serta menyadarinya bersama bahwa Rasulullah sendiri pernah melaksanakan bukuman rajam dan setelab itu kita pun melakukannya. Hal ini saya tegaskan kembali lantaran aku khawatir, karena telah berselang, akan ada seorang yang mengatakan: "Demi Allah kami tidak mendapatkan ayat rajam dalam kitabullah". Dengan meninggalkan suatu kewajiban yang benar-benar di turunkan Allah, maka mereka telah sesat. Hukuman rajam yang terdapat dalam kitabullah itu harus dijatubkan kepada laki-laki maupun perempuan yang berbuat zina mubshan, dengan syarat adanya bukti-bukti, kehamilan atau pengakuan dari dirinya sendiri. (HR. al-Bukbari)

Dari seluruh riwayat di atas dan lainnya, maka tampak jelas sekali bahwa ayat tersebut benar-benar telah diyakini Khalifah 'Umar

17 Imam Abi Abdillah Muhammad bin Ismail Ibnu Ibrahim bin al-Mughirah bin Bardabah al-Bukhari al-Ja'fiyy, Shabih Bukhari, Beirut: Dar al-Kitab Ilmiyyah, Juz VII, hlm. 341. 
bin Khaththab sebagai bagian dari al-Qur'an, walaupun sekarang tidak dapat ditemukan dalam al-Qur'an mushaf 'Utsmaniy. Hal ini yang menjadikan sebuah pertanyaan besar bagi kaum muslimin saat ini dari isi khutbah di atas. Bagaimana kebenaran ayat itu bisa dibuktikan. Ternyata 'Umar membatalkan mencantumkan ayat rajam dalam alQur'an bukan karena ia ragu bahwa ia benar-benar bagian dari alQur'an yang turun kepada Nabi Muhammad saw., akan tetapi karena kekhawatirannya akan tuduhan manusia bahwa ia telah menambahnambah al-Qur'an, sebab orang-orang tidak mengetahui dengan baik kalau ayat itu adalah bagian dari al-Qur'an. Maka demi menjaga diri dari tuduhan itu beliau merelakan untuk tidak memasukkannya.

Berbeda dengan pelaksanaan hukuman rajam yang dilaksanakan 'Ali bin Abi Thalib sebagaimana penjelasan hadits di bawah ini;

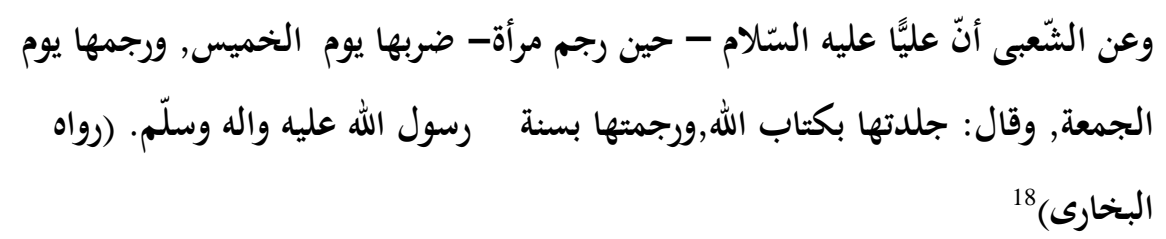

Artinya: Dari al-Sya'by, bahwasanya 'Ali As, ketika melaksanakan bukuman rajam terhadap seorang perempuan, ia mencambuknya pada hari Kamis dan merajamnya pada hari Jumu'at. Ia berkata: aku mencambuknya berdasarkan kitab Allah, dan merajamnya berdasarkan sunnab Rasulullah 'alabi wa alibi wa sallam”. (HR. al-Bukhari).

Dalam ketetapan hukum yang didasarkan pada hadits di atas dapat dipahami bahwa 'Ali memberlakukan hukuman rajam berdasarkan ketetapan yang diambil dari Nabi, bukanlah dari alQur'an.

Jika dilihat dalam beberapa dalil di atas, bahwa al-Qur'an dan alSunnah masih memegang hukum yang mengikat. Menurut logika syari'ah sebagai hukum keagamaan, sekali al-Qur'an berbicara secara jelas dan pasti, maka bagi orang-orang beriman tidak memiliki pilihan lain kecuali taat dan melaksanakannya.

18 Imam Abi 'Abdillah Muhammad bin Ism'ail Ibnu Ibrahim bin al-Mughirah bin Bardzabah al-Bukhari al-Ja’fiyy, op.cit., hlm. 335. 
Oleh karena itu, hukuman rajam telah diakui dan diterima oleh hampir semua fuqaha' dengan alasan bahwa hukuman rajam pernah dilaksanakan oleh Rasulullah dan telah menjadi ijma' para sahabat sesudahnya. Akan tetapi, hukuman rajam ini tidak diterima oleh kelompok Azariqah dari golongan Khawarij, dengan alasan, karena mereka ini tidak mau menerima hadits yang dijadikan dasar penjatuhan hukuman rajam tersebut tidak sampai pada tingkatan hadits mutawatir, tetapi hanya sebatas pada tingkatan hadits abad, meskipun derajat hadits tersebut shahih.

Kendatipun secara tegas Nabi telah menetapkan hukuman rajam bagi pelaku zina yang sudah pernah menikah, akan tetapi dalam diskursus fiqh terdapat beberapa friksi. Bagi Mu'tazilah, sebagian Syiah dan Khawarij hanya memberlakukan hukuman cambuk/dera saja (tidak hukuman rajam) bagi pelaku zina, baik yang sudah pernah menikah ataupun belum.

Alasan mereka adalah; pertama, hukum rajam adalah hukuman terberat dalam Islam yang semestinya dicantumkan secara pasti di dalam al-Qur'an, sebagaimana hukuman cambuk seratus kali yang tercantum dalam. QS. al-Nur: 2. Ternyata dalam QS. Al-Nur: 2 tersebut tidak menegaskan status pezina secara pasti apakah status pezinanya mubshan atau pezinanya ghairu mubshan. Nash al-Qur'an hanya menyebut sanksi cambuk seratus kali bagi pezina, padahal pada kesempatan lain al-Qur'an menunjuk secara jelas dan pasti sanksi bagi perbuatan pidana menuduh zina (qadzaf) dengan hukuman delapan puluh cambukan, sebagaimana yang tercantum dalam QS. al-Nur: 4.

Kedua, maksud dari QS. al-Nur: 2 adalah hanya menjelaskan bahwa hukuman bagi pelaku zina yang ada adalah hukuman cambuk seratus kali, sama sekali tidak menyebutkan hukuman rajam.

Ketiga, dalam QS. al-Nisa': 25, justru menyebutkan seperdua $(1 / 2)$ hukuman, jika pelakunya sebagai budak wanita, sehingga jika hukuman rajam diberlakukan, maka akan kesulitan untuk mengukur hukuman setengah dari hukuman rajam. ${ }^{19}$

Sementara argumentasi yang dibangun oleh golongan jumhur ulama' yang mengakui eksistensi hukuman rajam adalah; pertama,

\footnotetext{
19 Amin Abdullah, Madz̧bab Jogja Menggagas Paradigma Ushul Figh Kontemporer, Yogyakarta: ar-Ruzz Press, 2002, hlm. 222-223.
} 
hukuman rajam ditetapkan berdasarkan hadits Nabi. Bukankah salah satu fungsi dari hadits itu untuk memberikan penjelasan terhadap alQur'an?. Kedua, lafadz al-mubshanat pada QS. al-Nisa': 25 bermakna wanita merdeka, bukan wanita budak, karena hukuman rajam tidak dikenakan kepada wanita budak, tetapi hukuman rajam tersebut khusus bagi wanita merdeka. ${ }^{20}$

Ketentuan hadd rajam bagi pelaku zina mubshan ini didasarkan pada ketetapan sunnah Nabi yang diyakini sebagai sumber kedua hukum Islam setelah al-Qur'an. Selama dekade pertama Islam adalah suatu kebiasaan untuk merujuk kembali kepada biografi Nabi dan peristiwa-peristiwa dimana beliau terlibat didalamnya sebagai sirah (sejarah)-nya. ${ }^{21}$ Dapat dikatakan bahwa taat kepada Nabi merupakan kewajiban bagi umat Islam. Taat kepada Nabi, secara definitif berarti juga taat kepada Allah. ${ }^{22}$

Namun secara garis besar ketentuan-ketentuan hadd rajam dalam hukum pidana Islam dapat ditempuh dua cara, yaitu:

1. Menetapkan hukum berdasarkan nash.

2. Menyerahkan penetapannya kepada penguasa (ulil amr). ${ }^{23}$

Dalam cara yang pertama, Islam tidak memberikan kesempatan kepada penguasa (ulil amri) untuk menetapkan hukuman yang menyimpang dari ketentuan yang telah ditetapkan dalam al-Qur'an dan al-Sunnah. Hukuman-hukuman untuk tindak pidana yang termasuk dalam kelompok pertama ini berlaku sepanjang masa dan tidak berubah karena perubahan ruang dan waktu. Untuk cara yang kedua, Islam memberikan kesempatan yang luas kepada penguasa (ulil amri) untuk menetapkan macam-macam tindakan pidana dan hukumannya. Al-Qur'an dan al-Sunnah hanya memberikan ketentuan umum yang penjabarannya diserahkan kepada penguasa. Ketentuan umum tersebut adalah bahwa setiap perbuatan yang merugikan, baik

\footnotetext{
${ }^{20}$ Ibid.

${ }^{21}$ Wael B. Hallaq, Sejarah Teori Hukum Islam Pengantar Untuk Usul Fiqih Mazhab Sunni, Jakarta: Raja Grafindo Persada, hlm. 15.

${ }^{22} \mathrm{Ibid}$, hlm. 16.

23 Ahmad Wardi Muslich, Pengantar dan Asas Hukum Pidana Islam Fikih Jinayah, Jakarta: Sinar Grafika, 2004, hlm. 6.
} 
terhadap individu maupun masyarakat merupakan tindak pidana yang harus dikenakan hukuman. ${ }^{24}$

\section{Kesimpulan}

Berdasarkan uraian di atas dapat disimpulkan sebagai berikut:

1. Jika dilihat dari setting historis, maka penetapan hukuman rajam bagi pelaku zina mubshan itu didasarkan kepada hadits Nabi, baik secara qauliyah maupun fi'liyah. Akan tetapi, ada kesulitan dalam membedakan antara status teks sunnah mengenai apakah teks sunnah tersebut menjelaskan wahyu atau tidak. Hal ini dapat disimpulkan bahwa hukuman rajam dalam hukum pidana Islam itu bukan berasal dari syari'at Islam itu sendiri semata-mata yang dibawa oleh Nabi Muhammad saw, tetapi yang pasti bahwa hukuman rajam adalah berdasarkan nash atau ajaran agama sebelumnya, yaitu nash yang terdapat dalam Kitab Taurat. Hal ini dapat dilacak dari dasar normatif dari hukuman rajam ini adalah hadits-hadits Nabi yang mengacu kepada penerapan hukuman rajam bagi pelaku zina mubshan. Setidaknya Rasulullah saw. telah empat kali melaksanakan atau minimal memberitahukan pelaksanaan hukuman rajam bagi pelaku zina mubshan.

2. Hukuman rajam telah diakui dan diterima oleh hampir semua fuqaha' dengan alasan bahwa hukuman rajam pernah dilaksanakan oleh Rasulullah saw., dan telah menjadi ijma' para sahabat sesudahnya. Akan tetapi, hukuman rajam ini tidak diterima oleh kelompok Azariqah dari golongan Khawarij dan golongan Mu'tazilah dengan alasan bahwa mereka tidak mau menerima hadits yang dijadikan dasar penjatuhan hukuman rajam tersebut tidak sampai pada tingkatan hadits mutawatir, tetapi hanya sebatas pada tingkatan hadits abad, meskipun derajat hadits tersebut menurut ulama hadits adalah shahih.

\footnotetext{
${ }^{24}$ Ibid, hlm. 6-7.
} 


\section{DAFTAR PUSTAKA}

'Abd al-Qadir 'Audah, Al-Tasyri' al-Jinaiy al-Islamiy Muqaranan bi al-Qanun alWadl'iy, Juz II, Beirut: Dar al-Kitab al-Arabi, t.th.

Abdullah Ahmed an-Na'im, Dekonstruksi Syariah: Wacana Kebebasan Sipil,

Hak Asasi Manusia dan Hubungan Internasional Dalam Islam, Yogyakarta: LKiS dan Pustaka Pelajar, 1994.

Abdur Rahman I Doi, Tindak Pidana Dalam Syariat Islam, Jakarta: Rineka Cipta, 1992.

Ahmad Ali bin Hajar, Fath al-Bariy, Juz 12, Beirut: Dar al-Fikr, t.th.

Ahmad Wardi Muslich, Pengantar dan Asas Hukum Pidana Islam, cet. II, Jakarta: Sinar Grafika, 2006.

Amin Abdullah, Madzhab Jogja Menggagas Paradigma Ushul Fiqh Kontemporer, Yogyakarta: ar-Ruzz Press, 2002.

Husain Muhammad al-Maghribiy, Al-Badru al-Tamam, Juz IV, t.tp: Dar alWafa, 2005.

Ibnu Rusydi, Bidayah al-Mujtabid, Semarang: Asy Syifa, 1990.

Imam Abi 'Abdillah Muhammad bin Isma'il bin Ibrahim bin al-Mughirah bin Bardzbah al-Bukhari al-Ja'fiy, Shahih al-Bukhari, Beirut: Dar alKitab al-'Ilmiyyah, juz VII, t.th.

Imam Abi Husaen Muslim bin Hajjaj al-Qusaery al-Nasaburi, Shahih Muslim, juz II, Beirut: Dar al-Kutub al-Ilmiyah, t.th.

Imam Abi Husain Muslim bin Hajjaj al-Qusairy al-Nasaburiy, Shahih Muslim, juz II, Baeirut: Dar al-Kitab al-Ilmiyah, t.th.

Muhammad bin 'Abd al-Baqi bin Yusuf al-Zarqani al-Misri al-Azhari alMaliki, Syarh al-Zarqani 'ala Muwaththa', cet I, IV, Beirut: Dar al-Kutub Ilmiyah, 1990.

Tsalisah, Ensiklopedi Hukum Islam, Jilid III, Bogor: Batara Offset, t.th.

Wael B. Hallaq, Sejarah Teori Hukum Islam Pengantar Untuk Usul Fiqib Mąhab Sunni, Jakarta: Raja Grafindo Persada. 